\title{
The measured shallow temperature field in Britain
}

\author{
Jon Busby $^{1 a}$, Andrew Kingdon ${ }^{1}$, John Williams ${ }^{1}$ \\ ${ }^{1}$ British Geological Survey, Keyworth, Nottingham, NG12 5GG
}

ae-mail: jpbu@bgs.ac.uk

\begin{abstract}
The move towards a lower carbon society is likely to lead to a greater utilisation of geothermal heat as the UK meets the challenge of its EU renewable obligation to source $15 \%$ of its energy from renewables by 2020 . The shallow temperature field can be estimated, but measured temperatures are the most accurate methodology for defining the shallow heat resource. Available measured temperature data have been used to compile maps of temperatures at depths below ground level of 100, 200, 500 and $1000 \mathrm{~m}$. From these data regional trends and anomalies have been defined. From a consideration of all of the data a geothermal gradient of $28{ }^{\circ} \mathrm{C} \mathrm{km}{ }^{-1}$ has been calculated for the upper $1 \mathrm{~km}$ of the sedimentary crust which is slightly above the previously quoted value of $26{ }^{\circ} \mathrm{C} \mathrm{km}^{-1}$. Elevated temperatures have been mainly observed in eastern and southern England and have been attributed to convection within some of the thicker Permo-Triassic sandstones and the thermal blanketing effect of Triassic and Jurassic argillaceous rocks. Some of the depressed temperatures are associated with thick sequences of Carboniferous arenaceous rocks.
\end{abstract}

\section{Introduction}

Exploitation of the shallow heat resource within the United Kingdom (UK) is set to increase over the next decade. The UK has signed up to the EU renewable obligation that will require the UK to source 15\% of its energy from renewables by 2020 and has 
committed itself to sourcing 12\% of heat from renewables by 2020 (DECC, 2009). A proportion of this has the potential to be sourced from geothermal heat.

In the assessment of any geothermal prospect, subsurface temperature is the first parameter to be considered. Elevated temperatures do not necessarily indicate a viable geothermal resource as this depends on many factors including permeability, hydraulic transmissivity, heat capacity, thermal conductivity and sustainability. Improved designs for single borehole heat exchangers have enabled geothermal exploitation without the requirement for an aquifer (e.g. Lundershausen et al., 2004). Hence, where there is demand for geothermal energy temperature anomalies are the primary targets for the initial stages of any geothermal exploration programme. In a region such as Britain, which is not subject to active tectonics it is possible to consider a stable background temperature field. This will be determined by an upper boundary that comprises the ground surface, the effect of which is a temperature at a depth of $10-15 \mathrm{~m}$ that is equal to the mean annual soil temperature that is typically $1{ }^{\circ} \mathrm{C}$ higher than the mean annual air temperature (Rybach \& Sanner, 2000). Below this level the temperature will increase with depth at a rate set by the geothermal gradient that is itself determined by the vertical heat flow and the thermal conductivity of the rocks. Therefore in principle, if the geological succession is known it is possible to estimate the temperature at any depth.

In practice, observed temperatures will differ from estimated temperatures for a variety of reasons.

- Heat flow is not one dimensional, but will also be affected by lateral variations in thermal conductivity, a phenomenon often referred to as heat refraction. 
- Groundwater flow will transport heat by advection and within any permeable horizon there will be convection. Such mechanisms could create both high and low temperature anomalies. The most obvious examples of this in Britain are the thermal springs at Bath (Gallois, 2007) and in the Peak District (Brassington, 2007) where groundwater is able to rise relatively rapidly from depth through fractured Carboniferous Limestone.

- Internal heat production from natural radioactive decay within some buried granites will increase the heat flow. This will increase temperatures within the overlying sedimentary rocks especially where they have lower thermal conductivities. Heat flow measurements taken above buried granites should include an element for the extra heat production, but geothermal boreholes to measure heat flow are sporadically located. Hence, it is possible that buried heat production sources have not been identified.

- Heat from a variety of anthropogenic sources can leak from the surface in urban areas resulting in a decrease of temperature with depth. This effect has been reported by Banks et al. (2009) for a site in the UK where a reversed geothermal gradient was observed to a depth of $55 \mathrm{~m}$ and similar results have been reported from Osaka, Japan by Huang et al. (2009).

Therefore direct measurements of temperature remain the most accurate methodology for defining the shallow heat resource.

Previous publications of the temperature field in Britain have concentrated on temperatures in the depth range of $4-7 \mathrm{~km}$ (Downing and Gray, 1986a, b; Barker et al., 2000) since the purpose of those studies was to identify temperatures that might be suitable for geothermal electricity generation. In the past two decades it has become 
clear that the shallower heat, in the depth range above $1000 \mathrm{~m}$, is a substantial and more easily accessible heat resource. For depths down to 200 m this can be exploited by ground source heat pump technology (e.g. Sanner et al., 2003; Banks, 2009) and for greater depths by direct use applications (e.g. Lund and Freeston, 2005; Lund, 2010). To date there have been very few studies of shallow temperatures in Britain although there is increasing interest, e.g. Headon et al. (2009), Pike (2010).

\section{Data compilation}

This paper describes the amalgamation of temperature data from a number of sources to generate temperature data sets for four depth intervals. These depths are metres below ground level (mbgl) and not depths relative to Ordnance Datum, since in any geothermal exploration it is the depth of borehole that has to be drilled from the surface that is the key element in the project. Since mean annual air temperatures are dependent on topography it is possible that in the shallow data there may be a topographic signal.

The four depths at which temperatures have been compiled are 100, 200, 500 and 1000 mbgl. The three data sources are the Geothermal Catalogue, the digital national petrophysical data archive and hard copy temperature logs.

\section{The Geothermal Catalogue}

A catalogue of sub-surface temperature, heat flow, thermal conductivity and geochemistry data was compiled as part of the 'Investigation of the geothermal potential of the UK' programme, funded by the UK Department of Energy and the European Commission between 1976 and 1988. The catalogue was originally published in 1978 (Burley and Edmunds, 1978) and updated in three revisions; Burley and Gale (1982), Burley et al. (1984) and Rollin (1987). During this period there was 
considerable onshore drilling activity, mainly for hydrocarbons, but due to commercial restrictions it was not possible to access all known data.

The categories of temperature in the catalogue comprise the following,

- Equilibrium temperatures (EQM) are those taken specifically for the calculation of heat flow where the borehole was drilled months or years prior to temperature measurements allowing the borehole temperature to equilibrate with the surroundings.

- Bottom hole temperatures (BHT) were recorded during routine geophysical logging and record the maximum temperature, which is assumed to be at the base of the hole.

- Wireline logs (LOG) are temperature profiles recorded by a logging tool over a length of a borehole.

- Coal field measurements (CFM) were made at the end of horizontal boreholes specially drilled in coal mines.

- Mine water temperatures (MWT) are from small water flows issuing from rocks within a mine and all refer to Cornish mining.

- Virgin strata temperatures (VST) also refer to temperatures taken in coal mines in specially drilled boreholes, but where the temperature has been monitored over a period of time so that it is close to an equilibrium measurement.

- Drill stem tests (DST) are temperatures taken in hydrocarbon or water boreholes during drill stem tests. Since this involves the sampling of formation 
waters these temperatures should be less affected by the mud circulation than bottom hole temperatures.

The frequency distribution of these temperature data and any corrections that have been applied are discussed by Rollin (1987; 1995). The main correction is that applied to the BHT data (that comprise $50 \%$ of the catalogue data) in order to estimate equilibrium temperatures from transient temperatures measured during breaks in drilling. These corrections require the time since circulation of the drilling mud ceased $\left(t_{c}\right)$ and consist of an empirical correction derived from $t_{c}$ and the magnitude of the temperature or, in later revisions of the catalogue, derived from $t_{c}$ only. The BHT data where $t_{c}$ is not known will not have been corrected and are therefore likely to be under estimates of the temperature.

The data listings within the catalogue consist of temperatures at discreet depths. For the majority of sites only a few depth/temperature values are given. The exceptions are the equilibrium temperature boreholes where values are listed at 10 or $100 \mathrm{~m}$ depth intervals depending on the depth of the borehole. Therefore in order to produce temperature fields at depths of 100, 200, 500 and $1000 \mathrm{~m}$ some interpolation has been necessary. Interpolation of sub-surface temperatures must be done with care as the temperature gradient depends on the thermal conductivity over the section of interest. Since thermal conductivity data are not available, interpolation has been restricted to the ranges shown in Table 1 for the temperature field depths considered.

The vast majority of interpolations are based on the calculated temperature gradient at the depth of the temperature measurement. In a small minority of cases the interpolation is made between two temperatures that span the temperature field depth.

\section{The BGS digital national petrophysical data archive}


These data were interrogated in order to capture sub-surface temperature data added to the digital archive since the compilation of the Geothermal Catalogue. Data consist of downhole temperature curves taken from logging runs during breaks in drilling. Spurious values (or spikes) are a common problem in logging because of the hostile conditions which logging tools have to operate at (underwater and under high temperatures and pressure). Therefore rather than simply recording the temperature at, for instance, $200 \mathrm{mbgl}$, the interval has been bracketed by $\pm 5 \mathrm{~m}$ (i.e. from 195 to 205 mbgl). The interpolation ranges and the number of data points extracted for these data are shown in Table 1.

Increasingly oil and gas boreholes are drilled at an incline or substantially deviated from the vertical. In addition, for onshore Britain which is heavily populated and where space is at a premium, there is an increasing tendency for deviated wells as this allows prospects to be drilled from more accessible locations than vertically above the target well. This technology is mainly used in the oil and gas sector because deviated drilling is too expensive to be used routinely in the water or civil engineering sectors, although occasionally deviated wells are drilled in other sectors such as radioactive waste disposal. Hence, it is increasingly important to account for borehole deviation when estimating temperature/depth relationships. Given that well depth is usually recorded as depth downhole along the line of the borehole trajectory, it is necessary to correct into True Vertical Depth (TVD); that is the distance from a point below surface to a point vertically above it at ground level. This has been done by correlation with pre-existing TVD logs. In the case of horizontal wells these corrections may account for apparently long zones over which the data are averaged but in reality they are simply a reflection of the intersection of a steeply inclined 
(from vertical) to near horizontal borehole with an interval of a few vertical metres in height below ground level.

Another borehole attribute that might adversely affect results is casing which thermally insulates the borehole from the environment. Therefore careful examination of the logged interval in relation to casing depth has been made and logs through cased intervals eliminated.

Temperature log data has been collected for the oil and gas, coal, radioactive waste and water sectors, but there are no common quality standards operating across these industries. Data quality from comparatively inexpensive water industry logging is markedly poorer and more error prone than logging from other sectors.

\section{Hard copy temperature logs}

For many years, the BGS has been the custodian of a large quantity of hard copy petrophysical log data. These log data are derived mostly from either the hydrocarbon industry, British Coal exploration, or from BGS’ own onshore research, and contains a significant number of hard copy temperature logs. A simple methodology was utilised whereby temperature values where extracted from selected logs at intervals of $100 \mathrm{~m}$ depth below ground level, taking into account any deviations of the well from the vertical. Due to time constraints not all logs could be examined and so an approach based firstly on accessibility and quality of data, and then on maximum depth coverage and geographical location in relation to existing data points were applied. The interpolation ranges and the number of data points extracted for these data are also shown in Table 1.

\section{Results}


From Table 1 it can be seen that the total number of temperature measurements at depths of 100, 200500 and $1000 \mathrm{mbgl}$ are 497, 384, 323 and 544 respectively. Some simple statistics from these data are shown in Table 2. The median temperatures are slightly lower than the means indicating that a few high values are influencing the mean values. Hence the median values are preferred as representing central values. From the median values the representative geothermal gradient can be calculated. For the depth interval $0-100 \mathrm{~m}$ it equates to $22.0{ }^{\circ} \mathrm{C} \mathrm{km}^{-1}$; for $0-200 \mathrm{~m}$ it equates to 30.0 ${ }^{\circ} \mathrm{C} \mathrm{km}^{-1}$; for $0-500 \mathrm{~m}$ it equates to $26.4{ }^{\circ} \mathrm{C} \mathrm{km}^{-1}$; for $500-1000 \mathrm{~m}$ it equates to $29.2{ }^{\circ} \mathrm{C}$ $\mathrm{km}^{-1}$; and for $0-1000 \mathrm{~m}$ it equates to $27.8^{\circ} \mathrm{C} \mathrm{km}^{-1}$. These data therefore suggest that the previous estimate for the geothermal gradient for onshore Britain (as $26{ }^{\circ} \mathrm{C} \mathrm{km}{ }^{-1}$; Downing and Gray, 1986a) is slightly under estimated and a value of $28{ }^{\circ} \mathrm{C} \mathrm{km}^{-1}$ is preferred for the upper one km of the sedimentary crust.

Figure 1 shows the locations that are used in the discussion of the data overlaid on a simplified lithological map of British geology. The purpose of the analyses here are to define regional temperature anomalies. Isolated temperatures that are significantly above or below the median values have been removed from the data set as otherwise when the data are gridded an anomaly of large areal extent will be created. It is possible that these outlying high or low values could be due to errors in data collection or recording or they could be correct and result from local geological conditions. The remaining data have been gridded using a minimum curvature algorithm (Smith and Wessel, 1990) and contour plots are shown in Figures 2 to 5 along with the distribution of the data used in their compilation. The distribution of data points is inevitably concentrated over the Mesozoic and Carboniferous sedimentary basins, which were the focus for hydrocarbon and coal exploration, but with the exception of Scotland north of the Central Belt and parts of mid-Wales there 
is a reasonable distribution across most parts of Britain. Figure 6 shows the heat flow map for Britain (Lee et al., 1987; Downing \& Gray, 1986b; Rollin, 1995; Barker et al., 2000) which is the small quantity of heat that is conducted upwards from the interior of the earth.

The temperatures at a depth of $100 \mathrm{mbgl}$ (see Figure 2) can be compared against the median temperature of $12.5{ }^{\circ} \mathrm{C}$. There is a broad region extending from northeast England, through the East Midlands and extending into central England southwest of the Wash where temperatures are consistently above $14{ }^{\circ} \mathrm{C}$ and in places above $16{ }^{\circ} \mathrm{C}$. In southern England temperatures are closer to the median value with the exception of a hot spot to the north of the Isle of Wight defined by three boreholes around Winchester where temperatures are reported as high as $25^{\circ} \mathrm{C}$. These boreholes are separated by 4.6, 3.1 and $3.2 \mathrm{~km}$ and are located around the apex of an antiformal structure within the chalk. The temperature anomaly does not continue to depth and so it is possible that fracturing within the Cretaceous sequence associated with the antiform has led to the migration of warmer water from depth.Temperatures in the southwest of England are generally between $12-14{ }^{\circ} \mathrm{C}$, slightly above the median but a little less than expected given the high heat flows in this region. In northern England over the North Pennines temperatures are reported below $10^{\circ} \mathrm{C}$, but this is most likely a reflection of the high topography. Data are very sparse across the Southern Uplands and temperatures are around the median value across the Central Belt. Busby et al. (2009) have published a map of estimated temperatures at depths of $100 \mathrm{mbgl}$ based on a modelled ground surface temperature, the local heat flow and the bedrock geology and this is reproduced here in Figure 7. There is reasonable agreement between the measured and estimated data sets; the above median temperatures of east and central England are replicated as are the cooler temperatures of the North 
Pennines. In the southwest of England the pattern of temperature anomalies is in agreement, but the measured values are $1-2{ }^{\circ} \mathrm{C}$ below the estimated values.

In Figure 3 it can be seen that temperatures at depths of $200 \mathrm{mbgl}$ are again above the median value $\left(16.3^{\circ} \mathrm{C}\right)$ in the northeast of England and the East Midlands, but these elevated temperatures do not continue into central England. Average temperatures occur over most of southern England with two regions of elevated temperatures. The first is an arcuate belt from central England that curves around the London area and across the Weald to the south coast. The second is a broad zone over the Wessex Basin to the north of the Isle of Wight. Temperatures are around average in western England with lower values over the North Pennines. Data are again sparse over the Southern Uplands and Scotland. These measured data can again be compared to estimated values. It is too simplistic to assume that the surface bedrock geology is representative to a depth of $200 \mathrm{~m}$ and so the geological logs from 522 boreholes have been assigned average thermal conductivities. This information has then been combined with modelled ground surface temperatures and heat flow to generate the estimated temperatures at $200 \mathrm{mbgl}$ and this is shown in Figure 8. Estimated temperatures in the northeast of England and the East Midlands are elevated with values of over $18^{\circ} \mathrm{C}$ and, as seen in the measured data, this zone does not extend into central England. Over parts of the Wessex Basin estimated temperatures are raised, but the higher measured temperatures observed over the Weald are not seen in the estimated temperatures where values are generally less than $16{ }^{\circ} \mathrm{C}$.

The median temperature at $500 \mathrm{mbgl}$ is $23.5^{\circ} \mathrm{C}$ and as can be seen in Figure 4 there are several zones where this temperature is exceeded. In northern England, around Weardale, measured temperatures are in excess of $28{ }^{\circ} \mathrm{C}$ and elevated temperatures also occur in northeast England. In the East Midlands temperatures are generally 
above $28{ }^{\circ} \mathrm{C}$ and there is a zone around the Wash where they exceed $32{ }^{\circ} \mathrm{C}$. Values are above $24{ }^{\circ} \mathrm{C}$ in western England and exceed $32{ }^{\circ} \mathrm{C}$ in the Weald. Measured temperatures are above $28{ }^{\circ} \mathrm{C}$ in the northern Wessex Basin, north Devon and Cornwall. A significant zone of lower measured temperatures is observed in western central England with values generally below $20^{\circ} \mathrm{C}$ and in south Wales values are less than $24{ }^{\circ} \mathrm{C}$ but do increase towards the coast. A plot of the estimated temperature at $500 \mathrm{mbgl}$ is shown in Figure 9. It was produced from the same 522 boreholes used for the 200 mbgl estimated temperature map and involved assigning average thermal conductivities for the geological succession down to $500 \mathrm{~m}$ depth. The general pattern of anomalies is very similar to the $200 \mathrm{~m}$ depth estimated plot with above median temperatures in the northeast of England, the East Midlands and over parts of the Wessex Basin.

Figure 5 is a plot of the measured temperatures at depths of $1000 \mathrm{mbgl}$ where the median temperature is $38.1{ }^{\circ} \mathrm{C}$. There is a broad zone in northern England where temperatures are above $46{ }^{\circ} \mathrm{C}$ although it is only defined by a small number of measurements. Much of the East Midlands are above the median temperature although there is a complicated pattern of anomalies over the south Pennines that continues into central England where both high and low temperatures have been measured. Over large areas of the Wessex Basin and the Weald temperatures are above $46{ }^{\circ} \mathrm{C}$. The southwest of England is not represented in the plot due to a lack of measured data at $1000 \mathrm{~m}$ depth mbgl. The high heat flows associated with the Hercynian granites of the area (see Figure 6) should lead to anomalous high temperatures.

\section{Discussion}


The distribution of the measured data are variable. For the 100 and $200 \mathrm{~m}$ depth intervals there is reasonable coverage across most of England, the Central Belt in Scotland and the coastal regions of Wales. However for the deeper 500 and $1000 \mathrm{~m}$ depth intervals the majority of the data are concentrated in central and southern England. Any discussion of the regional temperature variation is limited by the data distribution. There is also considerable variability within the data. As stated earlier anomalies defined by single outlying high or low temperatures have been removed from the data set. These do not however remove every 'bulls eye' anomaly and in some areas with a reasonable data density there is a complex pattern of anomalies. These are most likely due to local variations and data errors. Clearly the data distribution is insufficient to define local anomalies and so the discussion is limited to regional trends.

All of the measured data sets show above median temperatures in the northeast of England and the East Midlands. This area corresponds with the subcrop of the East Yorkshire and Lincolnshire Basin, a sequence ranging in age from the Permian to the Cretaceous that dips gently to the east. The strata crop out to the east of the southern Pennines and the Permian is buried to depths of more than $2 \mathrm{~km}$ along the east Yorkshire coast. The main aquifer is the Triassic Sherwood Sandstone Group which has been studied for its geothermal potential (Gale et al., 1983). Its maximum thickness is over $500 \mathrm{~m}$ to the south of Bridlington and it is greater than $100 \mathrm{~m}$ thick over most of the basin. Due to the easterly dip of the strata cooler water could flow to depth, but the movement of water is reported to be slow and restricted to near the outcrop of the formation (Downing et al., 1987) as there is no flow from the confined aquifer to the east. Over much of the area the porosity of the sandstone exceeds $20 \%$ and its average intergranular permeability is estimated to exceed $200 \mathrm{mD}$, with 
fractures enhancing the overall permeability. The Sherwood Sandstone Group has an average thermal conductivity of around $3.4 \mathrm{~W} \mathrm{~m}^{-1} \mathrm{~K}^{-1}$ (Rollin, 1987). Hence from a combination of convective and conductive heat transport there is likely to be a low thermal gradient across the Sherwood Sandstone with enhanced temperatures near the top of the formation. However, it is overlain by the low thermal conductivity Mercia Mudstone Group and the argillaceous formations of the Jurassic which create a blanketing effect that leads to raised temperatures. It has been suggested (Downing et al., 1987) that saline waters from the Carboniferous may be recharging the Sherwood Sandstone from below and this would also contribute to increased temperatures. The 1000 mbgl surface intersects the Sherwood Sandstone and the underlying Carboniferous strata westwards from the east coast resulting in a more complicated set of temperature anomaly patterns. A small thermal high (the Eakring anomaly) is known in the East Midlands (Bullard and Niblett, 1951). Wilson and Luheshi (1987) have modelled this anomaly as arising from the ascent of water up a steep faulted anticline in the Lower Carboniferous Limestone. It is observed in the $500 \mathrm{mbgl}$ data but is less clear in the other data sets due to its local nature. Recharge of the Carboniferous Limestone occurs to the east and may cause local suppression of subsurface temperatures.

In southern England heat anomalies above the median values are variably developed. In the region between London and the south coast, anomalies are observed in the 200, 500 and $1000 \mathrm{mbgl}$ data sets, but farther west in the area to the north of the Isle of Wight anomalies are only seen in the 200 and $1000 \mathrm{mbgl}$ data (with the anomaly around Winchester in the $100 \mathrm{mbgl}$ data already noted above). This whole region is underlain by the Wessex Basin which has very different characteristics in the east and west. In the west there is a reasonably complete succession from the Cainozoic to the 
Permian, whilst in the east (the Weald sub basin) inversion has created an anticline with older, Cretaceous and Jurassic rocks exposed at the surface. Beneath the Weald, Jurassic rocks rest unconformably on Devonian rocks. The Triassic Sherwood Sandstone Group does not subcrop east of the Portsdown Middleton Fault and north of the Mere Fault (see Figure1). At a depth of $1000 \mathrm{mbgl}$ in the west there is generally a thick sequence of Jurassic clay and the temperature anomalies are most likely due to the blanketing effect of these low thermal conductivity rocks. The Sherwood Sandstone Group generally occurs at depths of between 1000 and $1800 \mathrm{mbgl}$ (with the exception of the Dorset Basin where depths are up to $2200 \mathrm{~m}$ ) and it is possible that convection and conduction within the sandstone may contribute to the anomaly. To the east, thick successions of Jurassic mudstones are still encountered at $1000 \mathrm{mbgl}$ and would again appear to be the cause of the high thermal anomalies. To the north of the basin, where temperatures are slightly less than the median temperature, boreholes at $1000 \mathrm{mbgl}$ prove Devonian sandstones or Lower Palaeozoic rocks which have higher thermal conductivities. In the $500 \mathrm{mbgl}$ data in the Weald Basin, boreholes again intersect thick sequences of Jurassic clays, whilst farther east sandier Cretaceous formations are encountered.

To the north of the Wessex Basin is the north-south trending Worcester Basin which can be located by the Kempsey borehole that was drilled in the northwest of the basin. At its centre it contains a great thickness of Permo-Triassic sandstones overlain by the Mercia Mudstone Group and, in the southwest of the basin, Lower Jurassic strata. At $1000 \mathrm{mbgl}$ the Kempsey borehole records a below median temperature of $32{ }^{\circ} \mathrm{C}$ in a sequence of Sherwood Sandstone overlain by (from surface to $348 \mathrm{~m}$ depth) Mercia Mudstone. In contrast, on the southwest margin of the basin higher than median temperatures are recorded in the $1000 \mathrm{mbgl}$ data. Here the sequence comprises 
Carboniferous Westphalian mudstones of the Grovesend Formation overlain by Mercia Mudstone and Jurassic clays. To the north, near Coventry, a series of boreholes define a distinct low temperature anomaly of $24^{\circ} \mathrm{C}$ or less in the $1000 \mathrm{mbgl}$ data. Carboniferous Westphalian strata extend from outcrop to depth, but unlike the Westphalian strata to the south these are arenaceous deposits of the Warwickshire Group. These data clearly indicate that thick sequences of higher thermal conductivity arenaceous strata lead to lower temperatures compared to areas where the blanketing effect of lower thermal conductivity mudstones enhance the temperature.

In south Wales thick sequences of arenaceous Coal Measures strata again lead to lower than median temperatures in the 1000, 500 and $200 \mathrm{mbgl}$ data. In northern England there is a broad anomaly, above $46{ }^{\circ} \mathrm{C}$, in the $1000 \mathrm{mbgl}$ data. The broad nature of this anomaly is due to the paucity of data and is centred on the Rookhope borehole which intersected the Weardale granite at a depth of 390 m (Dunham et al., 1965) and the Brafferton 1 borehole that intersects a thick sequence of Carboniferous limestone and may represent a localised anomaly. A thermal high is expected across northern England due to the buried Weardale granite which has elevated heat production (Downing and Gray, 1986a, b) and is overlain by relatively low thermal conductivity Carboniferous sedimentary rocks that will contribute to a blanketing effect. High temperatures were confirmed by the Eastgate borehole (Manning et al., 2007) drilled only a few kilometres from Rookhope which reported a BHT of $46.2{ }^{\circ} \mathrm{C}$ at a depth of $995 \mathrm{~m}$ (compared to $40.4^{\circ} \mathrm{C}$ at a depth of $806 \mathrm{~m}$ at Rookhope). Elevated temperatures are also known in Cornwall from the Rosemanowes HDR project where a BHT of $79{ }^{\circ} \mathrm{C}$ was recorded at a depth of $2 \mathrm{~km}$ in the Carnmenellis granite (Parker, 1999). To date there are no other deep temperature measurements in Cornwall and the 
majority of the measurements on the shallower depth plots are mine water temperatures.

Exploitation of direct use geothermal energy is set to increase especially as incentives (e.g. Renewable Heat Incentive in the UK) are introduced in order to meet governmental targets for carbon reduction and an increased utilisation of renewable heat. Lund (2010) reports a 79\% increase in worldwide direct use geothermal between 2005 and 2009, growing at a compound rate of $12.3 \%$ annually. For the depths and temperatures discussed here likely UK growth areas for geothermal direct use heat are greenhouses and open ground heating, bathing and swimming, aquaculture and single borehole heat exchangers. Elevated temperatures in the very shallow section will increase the heating efficiency of ground source heat pump systems.

\section{Conclusions}

This paper has compiled temperature data in the depth range down to $1000 \mathrm{mbgl}$ for Britain. These data are difficult to interpret due to an uneven distribution in location and depth, different measurement procedures and a lack of quality control. However, they are the only dataset of measured temperatures and represent the ground truth for estimated temperatures. Isolated high and low values are evident in the data and these could be localised anomalies or errors. Since the purpose of the analyses has been to define regional anomalies, extreme single point low and high values have been removed. Other single point anomalies still exist, but these have a less distorting effect than the extreme values.

From a consideration of all of the data a geothermal gradient of $28{ }^{\circ} \mathrm{C} \mathrm{km}$-1 has been calculated for the upper $1 \mathrm{~km}$ of the sedimentary crust which is slightly above the previously quoted value of $26{ }^{\circ} \mathrm{C} \mathrm{km}^{-1}$ (Downing and Gray, 1986a). In regions 
underlain by non-granitic crystalline rock the gradient will be lower due to their generally higher thermal conductivities and in regions underlain by heat producing granites it will be higher. Elevated temperatures have been mainly observed in eastern and southern England and have been attributed to convection within some of the thicker Permo-Triassic sandstones and the thermal blanketing effect of Triassic and Jurassic argillaceous rocks. Some of the depressed temperatures are associated with thick sequences of Carboniferous arenaceous rocks.

Temperature maps with an improved distribution of contours will ultimately depend on estimated and measured data for their compilation. The estimated data presented here show fairly good agreement with the measured data, but they are still based on single borehole locations. Improved estimations will require 3D geological models down to the depth of interest that will allow temperature variations caused by groundwater movements as well as the thermal conductivity variations to be taken into account.

\section{Acknowledgements}

This paper is published by permission of the Executive Director of the British Geological Survey (NERC).

\section{References}

Banks, D., 2009. Introduction to thermogeology and the exploitation of ground source heat. Quarterly Journal of Engineering Geology and Hydrogeology, 42, 283-293.

Banks, D., Gandy, C. J., Younger, P. L., Withers, J. and Underwood, C. 2009. Anthropogenic thermogeological 'anomaly' in Gateshead, Tyne and Wear, UK. Quarterly Journal of Engineering Geology and Hydrogeology, 42, 307-312. 
Barker, J. A., Downing, R. A., Gray, D. A., Findlay, J., Kellaway, G. A., Parker, R. H. and Rollin, K. E. 2000. Hydrogeothermal studies in the United Kingdom. Quarterly Journal of Engineering Geology and Hydrogeology, 33, 41-58.

Brassington, F. C. 2007. A proposed conceptual model for the genesis of the Derbyshire thermal springs. Quarterly Journal of Engineering Geology and Hydrogeology, 40, 35-46.

Bullard, E. C. and Niblett, E. R. 1951. Terrestrial heat flow in England. Monthly Notices of the Royal Astronomical Society. Geophysical Supplement, 6, 222-238.

Burley, A J and Edmunds, W M. 1978. Catalogue of geothermal data for the land area of the United Kingdom.. Investigation of the Geothermal Potential of the UK, Department of Energy, London.

Burley, A J and Gale, I N. 1982. Catalogue of geothermal data for the land area of the United Kingdom. First revision: August 1981. Investigation of the Geothermal Potential of the UK, Institute of Geological Sciences, Keyworth.

Burley, A J, Edmunds, W M and Gale, I N. 1984. Catalogue of geothermal data for the land area of the United Kingdom. Second revision: April 1984. Investigation of the Geothermal Potential of the UK, British Geological Survey, Keyworth.

Busby, J., Lewis, M., Reeves, H. and Lawley, R. 2009. Initial geological considerations before installing ground source heat pump systems. Quarterly Journal of Engineering Geology and Hydrogeology, 42, 295-306.

DECC, 2009. The UK Renewable Energy Strategy. Department of Energy and Climate Change, HM Government, 238 p. 
Downing, R. A., Edmunds, W. M. and Gale, I. N. 1987. Regional groundwater flow in sedimentary basins in the UK. In: Goff, J. C. and Williams, B. P. J. (eds.) Fluid flow in sedimentary basins and aquifers. Geological Society Special Publication, 34, 105-125.

Downing, R. A. and Gray, D. A. (eds.) 1986a. Geothermal Energy - The potential in the United Kingdom. HMSO, London.

Downing, R. A. and Gray, D. A. 1986b. Geothermal resources of the United Kingdom. Journal of the Geological Society, London, 143, 499-507.

Dunham, K. C., Dunham, A. C., Hodge, B. L. and Johnson, G. A. L. 1965. Granite beneath Visean sediments with mineralization at Rookhope, northern Pennines. Quaterly Journal of the Geological Society London, 121, 383-417.

Gale, I. N., Smith, I. F. and Downing, R. A. 1983. The post-Carboniferous rocks of the East Yorkshire and Lincolnshire Basin. Investigation of the Geothermal Potential of the UK, Institute of Geological Sciences.

Gallois R. 2007. The formation of the hot springs at Bath Spa, UK. Geological Magazine, 144, 741-747.

Headon, J, Banks, D, Waters, A and Robinson, V K. 2009. Regional distribution of ground temperature in the Chalk aquifer of London, UK. Quarterly Journal of Engineering Geology and Hydrogeology, 42, 313-323.

Huang, S., Taniguchi, M., Yamano, M. and Wang, C. H. 2009. Detecting urbanization effects on surface and subsurface thermal environment — A case study of Osaka. Science of The Total Environment, 407, 3142-3152 
Manning, D. A. C., Younger, P. L., Smith, F. W., Jones, J. M., Dufton D. J. and Diskin, S. 2007. A deep geothermal exploration well at Eastgate, Weardale: a novel exploration concept for low-enthalpy resources. Journal of the Geological Society, London, 164, 371-382.

Lee, M K, Brown, G C, Webb, P C, Wheildon, J and Rollin, K E. 1987. Heat flow, heat production and thermo-tectonic setting in mainland UK. Journal of the Geological Society, London, 144, 35-42.

Lund, J. W. 2010. Direct utilization of geothermal energy. Energies, 3, 1443-1471.

Lund, J. W. and Freeston, D. H. 2005. Direct application of geothermal energy: 2005 Worldwide review. Geothermics, 34, 691-727.

Lundershausen, S., Niemann-Delius, Ch., Herzog, Ch. Preuße, A., Schloenbach, M., Oesterreich, B. and von Hagke, Ch., 2004. Erdwärme für das SuperC - Die Geothermiebohrung RWTH-1 - erste Erfahrungen. Glückauf, 140 (12), S. 583591.

Parker, R. H. 1999. The Rosemanowes HDR Project 1983-1991. Geothermics, 28, 603-615.

Pike, D. 2010. Thermogeology and fluid conductivity of the Chalk aquifer around the western extent of the London Basin syncline. MSc Thesis (Hydrogeology), School of Earth and Environment, University of Leeds, UK.

Rollin, K. E. 1987. Catalogue of geothermal data for the land area of the United Kingdom. Third revision: April 1987. Investigation of the Geothermal Potential of the UK, British Geological Survey, Keyworth. 
Rollin, K. E. 1995. A simple heat-flow quality function and appraisal of heat-flow measurements and heat-flow estimates from the UK Geothermal Catalogue. Tectonophysics, 244, 185-196.

Rybach, L and Sanner, B. 2000. Ground-source heat pump systems; the European experience. Geo-Heat Center Bulletin, 21, No. 1, 16-26.

Sanner, B., Karytsas, C., Mendrinos, D. And Rybach, L., 2003. Current status of ground source heat pumps and underground thermal energy storage in Europe. Geothermics, 32, 579-588.

Smith, W. H. F. and Wessel, P. 1990. Gridding with continuous curvature splines in tension. Geophysics, 55, 293-305.

Wilson, N. P. and Luheshi, M. N. 1987. Thermal aspects of the East Midlands aquifer system. In: Goff, J. C. and Williams, B. P. J. (eds.) Fluid flow in sedimentary basins and aquifers. Geological Society Special Publication, 34, 157-169. 


\section{List of Figures and Tables}

Figure 1. Location map of place names, regions and faults referred to in the text overlaid on a simplified lithological map of geology.

Figure 2. Measured temperatures at $100 \mathrm{~m}$ depth below ground level. Measurement locations are indicated by the black dots.

Figure 3. Measured temperatures at $200 \mathrm{~m}$ depth below ground level. Measurement locations are indicated by the black dots.

Figure 4. Measured temperatures at $500 \mathrm{~m}$ depth below ground level. Measurement locations are indicated by the black dots.

Figure 5. Measured temperatures at $1000 \mathrm{~m}$ depth below ground level. Measurement locations are indicated by the black dots.

Figure 6. Heat flow map of Britain.

Figure 7. Estimated temperatures at depths of $100 \mathrm{~m}$ below ground level based on a modelled ground surface temperature, the local heat flow and the bedrock geology, after Busby et al. (2009).

Figure 8. Estimated temperatures at $200 \mathrm{~m}$ depth below ground level. The estimates are modelled using a 1D heat conduction model from 522 boreholes, the locations of which are indicated by the black dots.

Figure 9. Estimated temperatures at $500 \mathrm{~m}$ depth below ground level. The estimates are modelled using a 1D heat conduction model from 522 boreholes the locations of which are indicated by the black dots.

Table 1. Interpolation ranges used for calculating the temperatures at depths of 100, 200, 500 and $1000 \mathrm{mbgl}$ and the number of compiled temperatures at those depths.

Table 2. Mean and median temperatures from all of the compiled data at depths of 100, 200, 500 and 1000 mbgl. 


\begin{tabular}{|c|c|c|c|c|c|c|c|}
\hline Depth (mbgl) & \multicolumn{3}{|c|}{ Interpolation range (mbgl) } & \multicolumn{4}{c|}{ No. of temperatures } \\
\hline & $\begin{array}{c}\text { Geothermal } \\
\text { Catalogue }\end{array}$ & $\begin{array}{c}\text { Digital } \\
\text { archive }\end{array}$ & $\begin{array}{c}\text { Hard copy } \\
\text { logs }\end{array}$ & $\begin{array}{c}\text { Geothermal } \\
\text { Catalogue }\end{array}$ & $\begin{array}{c}\text { Digital } \\
\text { archive }\end{array}$ & $\begin{array}{c}\text { Hard copy } \\
\text { logs }\end{array}$ & Total \\
\hline 100 & $50-150$ & $97.5-102.5$ & $100-100$ & 133 & 290 & 74 & 497 \\
\hline 200 & $150-250$ & $195-205$ & $200-200$ & 221 & 87 & 76 & 384 \\
\hline 500 & $400-600$ & $495-505$ & $500-500$ & 200 & 67 & 56 & 323 \\
\hline 1000 & $800-1200$ & $995-1005$ & $1000-1000$ & 485 & 27 & 32 & 544 \\
\hline
\end{tabular}

Table 1. Interpolation ranges used for calculating the temperatures at depths of 100, 200, 500 and $1000 \mathrm{mbgl}$ and the number of compiled temperatures at those depths. 


\begin{tabular}{|l|c|c|}
\hline & Mean temp & Median temp \\
\hline $\begin{array}{l}\text { Measured ground temperature from the Geothermal } \\
\text { Catalogue }\end{array}$ & 10.2 & 10.3 \\
\hline $100 \mathrm{mbgl}$ temperature & 13.6 & 12.5 \\
\hline $200 \mathrm{mbgl}$ temperature & 17.3 & 16.3 \\
\hline $500 \mathrm{mbgl}$ temperature & 24.7 & 23.5 \\
\hline $1000 \mathrm{mbgl}$ temperature & 38.7 & 38.1 \\
\hline
\end{tabular}

Table 2. Mean and median temperatures from all of the compiled data at depths of 100, 200, 500 and 1000 mbgl. 


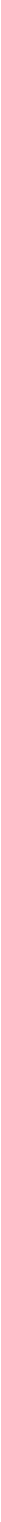




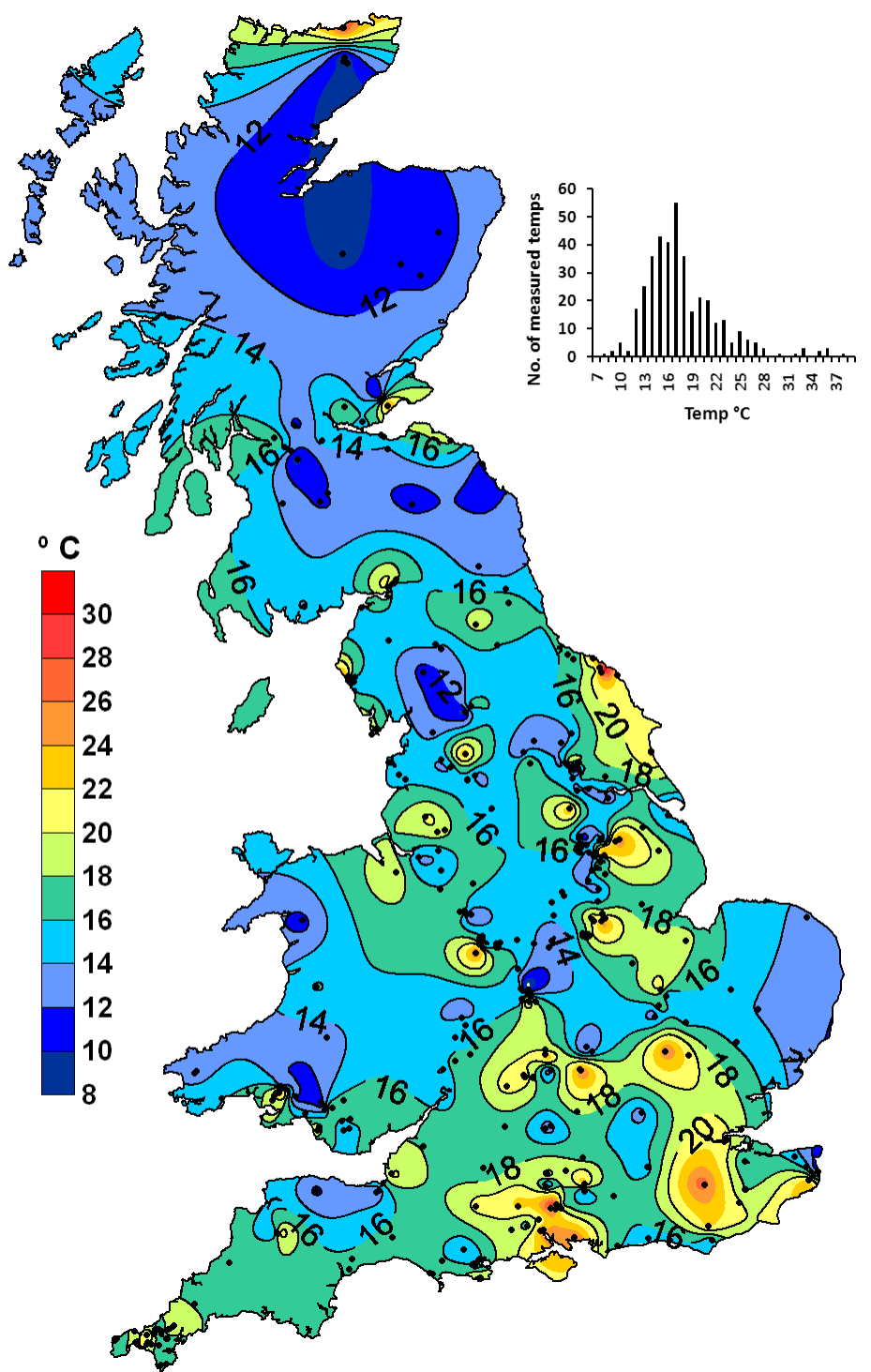




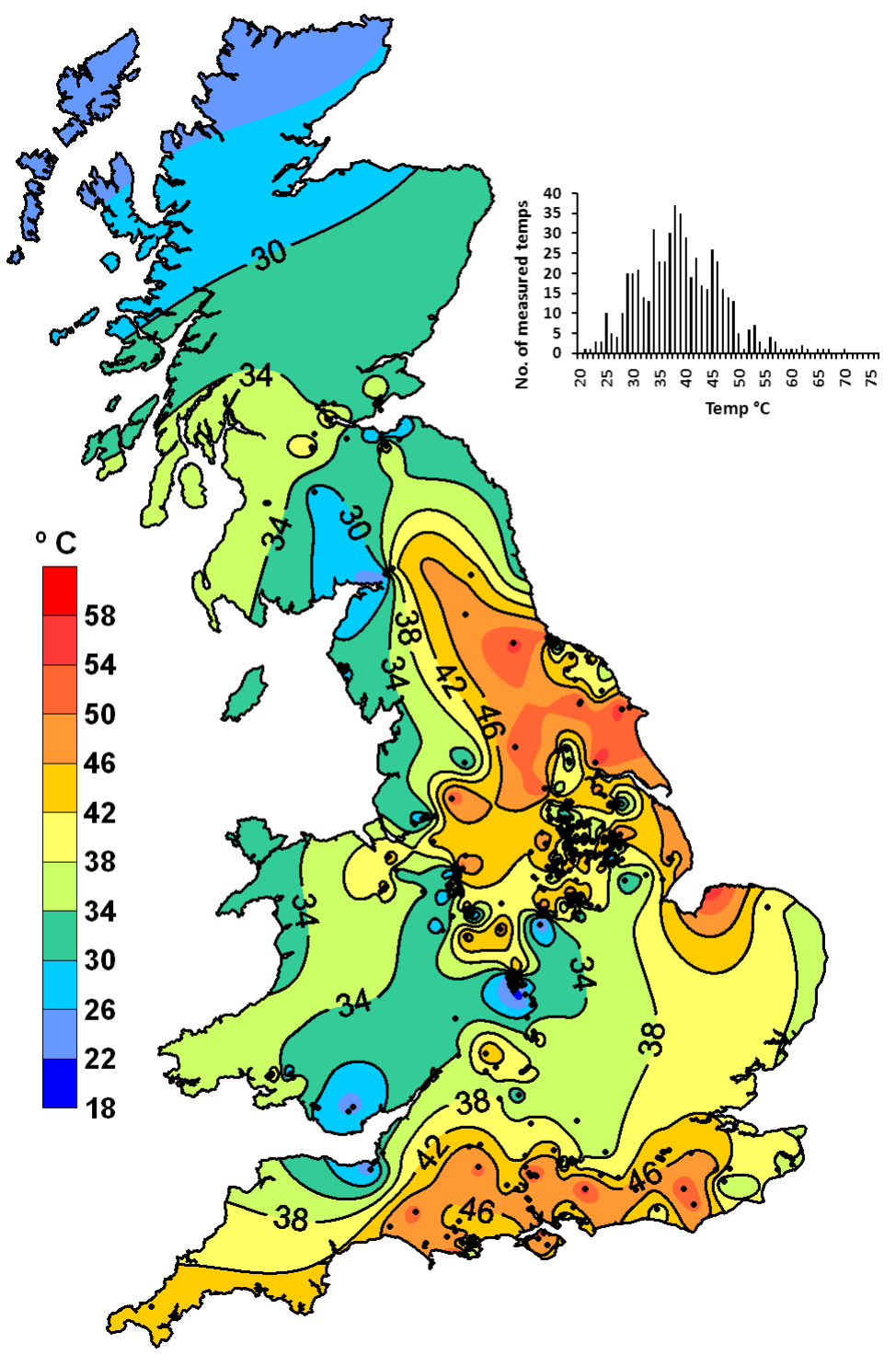




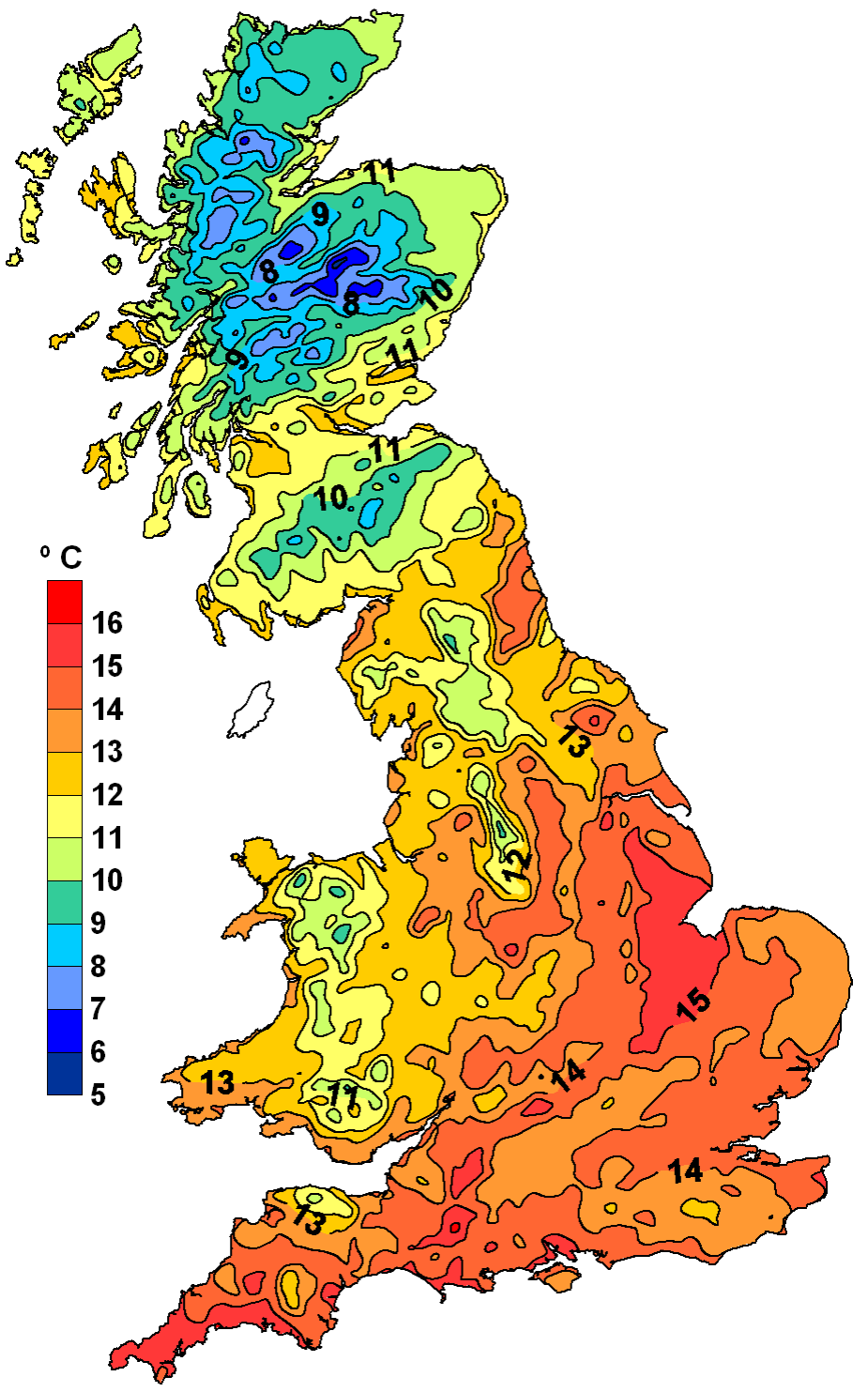




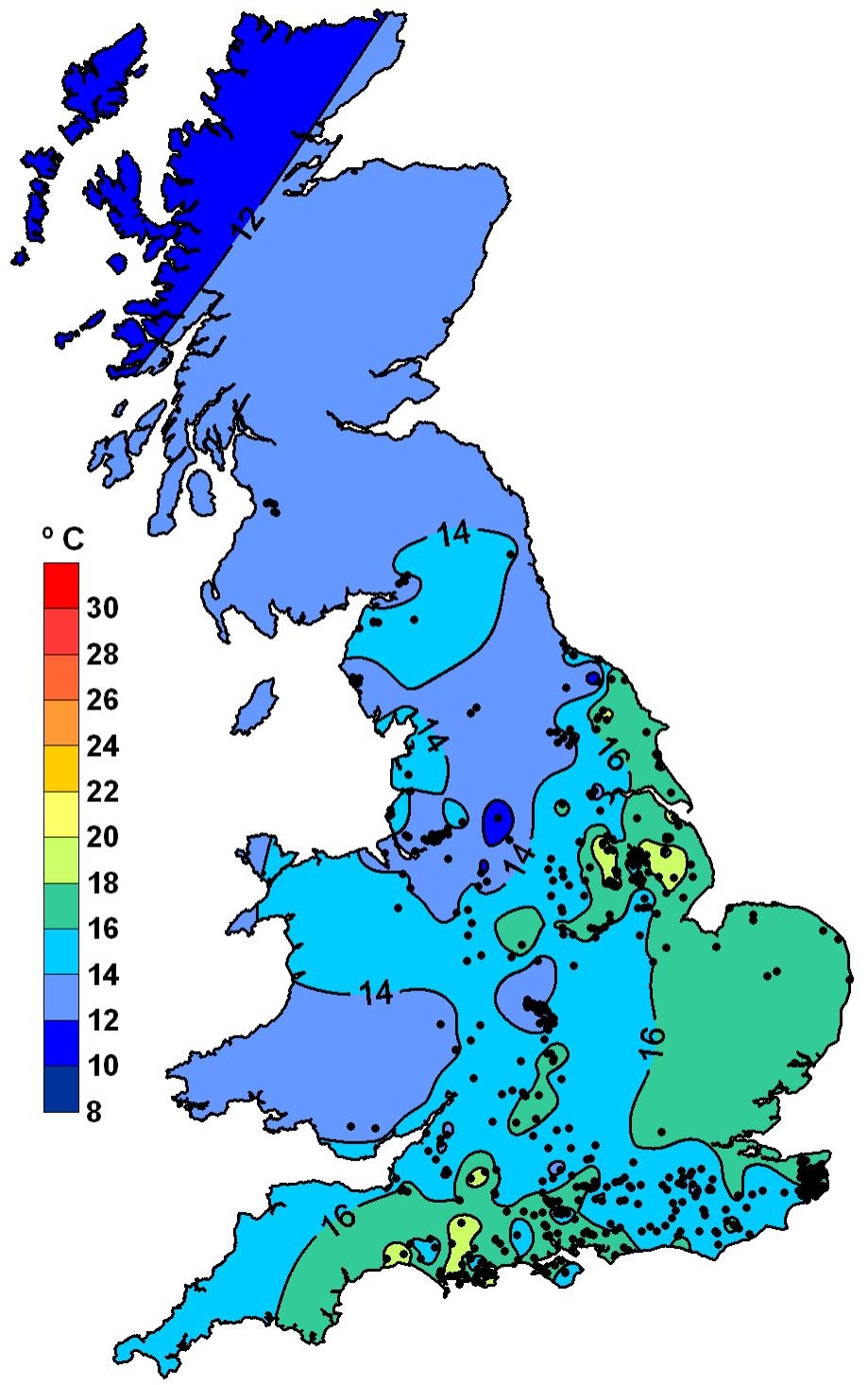


